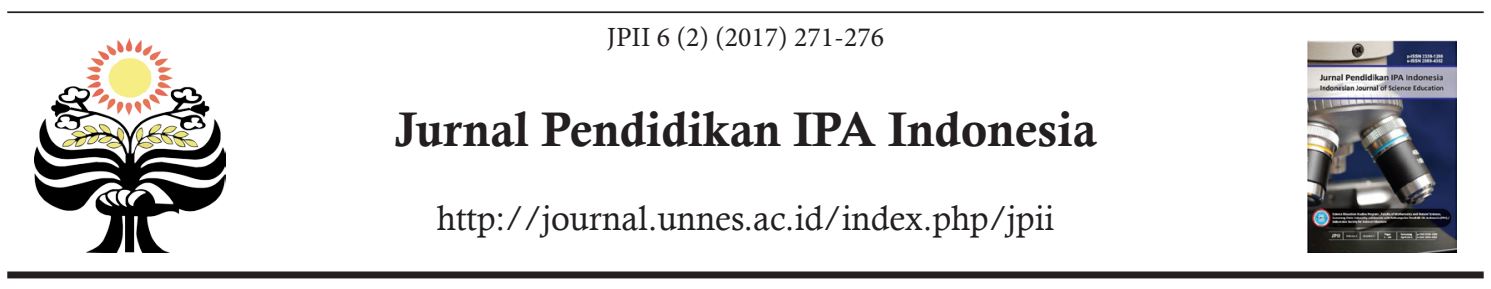

\title{
CAPTURING THE PCK ABILITY OF PROSPECTIVE SCIENCE TEACHERS USING CoRe AND PaP-eR
}

\author{
S. Nurmatin ${ }^{* 1}$, W. Purwianingsih ${ }^{2}$ \\ ${ }^{1}$ Department of MI Teacher Education, Sekolah Tinggi Agama Islam Tasikmalaya, Indonesia \\ ${ }^{2}$ Department of Biology Education, Universitas Pendidikan Indonesia, Indonesia
}

DOI: $10.15294 /$ jpii.v6i2.9507

Accepted: April 19 ${ }^{\text {th }}, 2017$. Approved: July 18 ${ }^{\text {th }}, 2017$. Published: October $17^{\text {th }}, 2017$.

\begin{abstract}
This study involving prospective science teachers at SMP aims to portray the ability of Pedagogical Content Knowledge (PCK) of the teachers via resource folios. Resource folios in question are the core and PaP-eRs made by the prospective science teachers when carrying out the "Program Pengalaman Lapangan" (PPL). The subjects were six candidates conducting PPL at a junior high school and were assigned by the class teachers to teach Grade VII. The instrument used as a means of collecting data in this research is the CoRe and PaP-eRs. The instrument has been analyzed using an analytical format. The result of CoRe and PaP-eRs analysis shows that the learning activities are carried out on the whole in accordance with lesson plans that have been rendered previously. However, the instruction plan is focused more on the CoRe content materials to be studied, while the narrative of learning implementation in the PaP-eRs is emphasized more on learning activities. The results show that the PCK ability of prospective teachers still do not show the integration between content capability and pedagogical ability.
\end{abstract}

(C) 2017 Science Education Study Program FMIPA UNNES Semarang

Keywords: pedagogical; CoRe; PaP-eRs

\section{INTRODUCTION}

The results of several studies assumed that in order to implement the teaching practice, a teacher needs some knowledge that underlies his teaching activities (Brown et al., 2013; Hanuscin, 2013; Seung, 2013; Seung et al., 2012). In other words, becoming a teacher requires a basic knowledge to carry out learning. The basic knowledge that teachers need to have is focused on developing teacher knowledge in learning that is divided into three knowledge groups: pedagogical knowledge, knowledge of learning content and knowledge that integrates content with pedagogy (Gess-Newsome et al., 2017; Seung, 2013; Seung et al., 2012). Of the three basic knowledge, the most important knowledge possessed by teachers is the knowledge that integrates material content

*Address Correspondence:

E-mail: suci.nurmatin@gmail.com with pedagogy (Anwar et al., 2013; Aydeniz \& Kirbulut, 2014; Nilsson, 2014; Seung, 2013). The knowledge that integrates content knowledge with pedagogy, by Shulman (1987), is called Pendagogical Content Knowledge (PCK).

Pendagogical Content Knowledge (PCK) was first introduced by Shulman (1987) as a major component of learning, emphasizing that learning is not just knowledge of material content but learning is an integration of content knowledge with pedagogical knowledge (Brown et al., 2013 ; Donnelly \& Hume, 2015; Hanuscin, 2013; Rich, 2009; Nilsson \& Loughran, 2012). In Hanuscin (2013), Shulman argues that PCK is a fundamental component of the knowledge base for teaching. Others argue that PCK is part of an academic building that shows interesting ideas related to what and how to teach (Iserbyt et al., 2017; Sagır \& Küçükaydın, 2016). From these statements, the authors argue that PCK is an 
integration of knowledge content with pedagogy that serve as the basis for carrying out learning. Currently every learning process in Indonesia is managed by the government.

In the Ministerial Regulation No. 65 of 2013, the government directs the learning process to include three domains, namely, attitudes, knowledge, and skills. To create the learning process as expected in the Ministerial Regulation No. 65 of 2013, the government regulates the competencies that must be owned by teachers. Competencies that must be owned by teachers are listed in the Ministerial Regulation No. 65 of 2013; they are pedagogy competence, personality competence, social competence, and professional competence. Two of the five competencies listed in the Ministerial Regulation No. 16 of 2007 having an important role in the learning activities are pedagogical competence and professional competence. Pedagogy competence includes teacher ability in understanding learning and teaching theories and everything related to learners, whereas professional competence includes teacher ability in understanding subject matter. Therefore, pedagogy competence and professional competence are parallel to PCK ability which is disclosed by Nilsson \& Vikström (2015); that is, PCK is the knowledge of integrating the subject matter knowledge and pedagogical knowledge. Based on Government Regulation and expert research results, it can be argued that every teacher needs to have PCK ability to carry out his learning.

A teacher will have good PCK skills if his skill is developed from the time of his education to become a teacher, he can be called a prospective teacher. In line with the rules stating that a prospective teacher should not only demonstrate knowledge and teaching skills in order to achieve the learning objectives, but he must demonstrate knowledge in determining learning strategies that can involve learners. Field findings based on the questionnaires to several prospective teachers indicates that the learning process can be used for learning activities. However, prospective teachers do not show how to teach a particular concept to be accepted by learners. Overall, based on the questionnaire, the teacher candidates revealed that the most important thing in learning is the interaction between teachers and students. This is in accordance with the results of previous studies which reveal that prospective teachers are unaware of the involvement of pedagogy and the act of facilitating students in a lesson (Hume \& Berry, 2011). Due to the importance of PCK skills of prospective teachers, it is necessary to analyze the PCK ability of prospective teachers.

The PCK ability of prospective teacher can be introduced in some courses related to the education of a lesson, and it will be more noticeable when prospective teachers follow the Field Experience Program (Wahyuni, 2015). Tools that can be used to analyze the PCK ability of prospective teacher are Content Representation (CoRe) and Pedagogical and Professional Experience Repertories (PaP-eRs). CoRe and PaP-eRs are resource folios used to capture the PCK ability of teacher and prospective teacher as they explicitly demonstrate the relationship between content knowledge and teaching and learning skills of science teachers and prospective science teachers (Hume \& Berry, 2011; Sagır \& Küçükaydın, 2016) .

CoRe is a format composed of rows and columns. The highest row shows the main topic, followed by the main idea which represents the main topic (Bertram \& Loughran, 2012). Columns in the CoRe format are composed of two, that is, the right column and the left column. The left column is comprised of eight questions related to content knowledge and pedagogy knowledge, while the right column shows answers from prospective teachers based on the main idea predetermined (Loughran et al., 2012). Based on expert opinions about CoRe, it can be said that CoRe can be used to capture the PCK ability of prospective teachers. The other CoRe, the other element that is used to capture the PCK ability is PaP-eRs.

PaP-eRs is a narration from learning implementation which highlights aspects of the subject matter being taught (Loughran et al., 2012). PaPeRs highlights learning that has planning and activities like student responses, interaction between students and learning media, and the result of student learning assessment. From expert opinions, it can be said that CoRe and PaP-eRs can integrate subject matter knowledge with pedagogical knowledge of prospective teachers ranging from planning to implementation of learning. Therefore, based on the above description related to the basic knowledge that must be possessed by teacher candidates, that is, knowledge that integrates content and pedagogy (PCK), the authors conduct research that analyzes the $\mathrm{PCK}$ ability of prospective teachers by using CoRe and PaP-eRs. This study aims to capture the ability of prospective teachers in planning and implementing learning in the classroom through resource folios. 


\section{METHODS}

Two junior high schools in Bandung serve as a place of research by involving six prospective teachers conducting teaching practice through "PPL" at the said schools as research subjects. Prospective teachers who serve as research subjects are prospective teachers assigned by the class teachers at the schools to teach the seventh graders. The research method used is qualitative, that is, one that does not give treatment in implementation (Creswell, 2012). The research describes the ability of prospective teachers in integrating subject matter knowledge with pedagogy knowledge through CoRe and PaP-eRs of the same content. The study began by studying the curriculum used at the chosen schools where prospective teachers conducted the "PPL". After a review of curriculum, the prospective teachers were required to fill in the CoRe as part of lesson planning. Then, after carrying out learning, the prospective teachers were requested to reflect on learning through the making of a narrative called PaP-eRs. Each prospective teacher's implementation of learning was recorded by video. The video was used by the prospective teachers to make learning reflection (PaP-eRs). CoRe and PaP-eRs made by the prospective teachers were next analyzed using format analysis.

\section{RESULTS AND DISCUSSION}

Capturing the PCK ability of teachers or prospective teachers is indicated by resource folios consisting of two elements, that is, CoRe and PaP-eRs (Loughran et al., 2012). CoRe is a format used in representing content and capturing the PCK ability of prospective teachers when planning a lesson (Nilsson \& Loughran, 2012; Nurmatin \& Rustaman, 2015). PaP-eRs is a supporting document. CoRe shapes the narrative of a teacher's teaching experience by underlining certain parts of learning implementation or aspects of the material taught. The CoRe is filled by the prospective teachers before implementing learning, while $\mathrm{PaP}-\mathrm{eRs}$ is created by the prospective teachers after implementing learning.

The PCK ability of six prospective teachers in the planning of learning is shown through CoRe. The PCK ability in planning the lesson shown through the correspondence between the main idea of matter and ability to elaborate every main idea according to eleven components in the CoRe. The eleven components in the CoRe are in the form of questions. These eleven questions represent the knowledge of the prospective teachers related to the concept that must be understood by students. The ability of students to accept the concept, the learning process that will be implemented up to the way the students are assessed are related to the main idea that emerges. The percentage of PCK ability of the prospective teachers on the basis of their ability in composing CoRe is shown in Figure 1.

Figure 1 shows that the mean score of PCK ability of six prospective teachers is under $50 \%$ with the number of ideas raised by each prospective teacher being different. The number of main ideas is not specified specifically for a particular material (Loughran et al., 2012). Therefore, prospective teachers have freedom in determining the number of main ideas from a particular material.

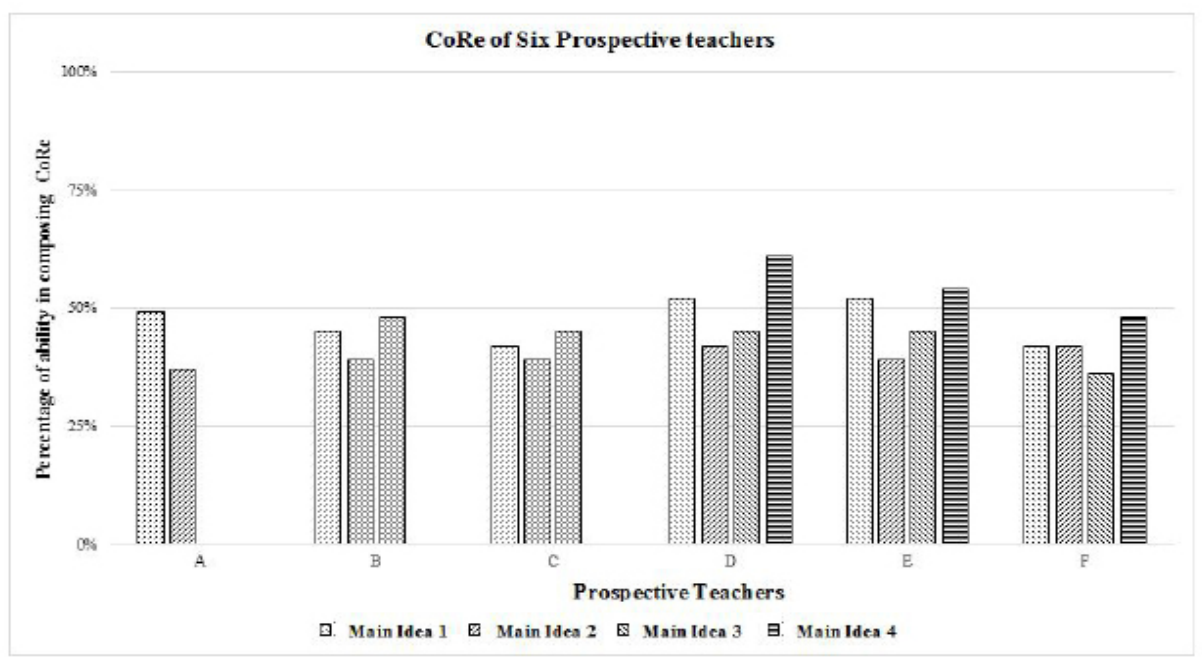

Figure 1. PCK Ability in Composing CoRe 
The number of main ideas determined by the prospective teachers starts from two up to four main ideas. The main idea illustrates the ability of the prospective teachers in determining the important concept that develops students' understanding (Loughran et al., 2012). Prospective teacher A writes just two main ideas; prospective teachers $B$ and $C$ write three main ideas each, while prospective teachers $\mathrm{D}, \mathrm{E}$, and $\mathrm{F}$ write four main ideas each. Overall, though the number of main ideas shown is different, the overall content of main ideas from six prospective teachers is the same.

However, three from six prospective teachers, namely, prospective teachers $\mathrm{A}, \mathrm{B}$, and $\mathrm{C}$ have not been able to write down the right idea in the concept. If the prospective teachers have not understood the concept, the prospective teachers have not described the concept to be accepted by students (Etkina, 2010). Therefore, prospective teachers $\mathrm{A}, \mathrm{B}$, and $\mathrm{C}$ have not been able to write main ideas correctly in the concept; they have not been able to translate a concept to be accepted by students. Based on Figure 1, evenly the main idea that has a low percentage is the second main idea. It happens because the six prospective teachers have difficulty especially in elaborating the initial concept that will affect the learning of the second main idea.

Furthermore, any predefined underlying idea is elaborated on the basis of the eleven components contained in the CoRe. The eleven com- ponents contained within CoRe should describe lesson planning to the main idea that has been specified. However, the prospective teachers' ability in describing the eleven components has not shown that yet. The ability shown by the prospective teachers in describing the eleven components of CoRe is just answering questions from the eleven components. This is especially in outlining the four components of CoRe related to material constraints, predictions of difficulty in teaching, early knowledge of students that may affect learning, and how to assess students.

Based on the result of the analysis of CoRe of six prospective teachers, the result obtained reveals that the ability of prospective teachers in the PCK planning of learning through CoRe has not shown the ability to integrate content knowledge and pedagogy. In addition to CoRe, the ability of prospective teachers in PCK is captured by making the narrative after the learning of PaP-eRs.

$\mathrm{PaP}-\mathrm{eRs}$ created by the prospective teachers in the form of narrative is based on learning that has been done by the prospective teachers. The prospective teachers create the PaP-eRs based on the video recording of the implementation of learning so that every implementation of learning is reflected. But in reality it is not the case. In reality three prospective teachers create $\mathrm{PaP}$-eRs based only on memory, so the result is a narrative on learning in outlines only. The ability of prospective teachers in creating PaP-eRs is shown in Figure 2.

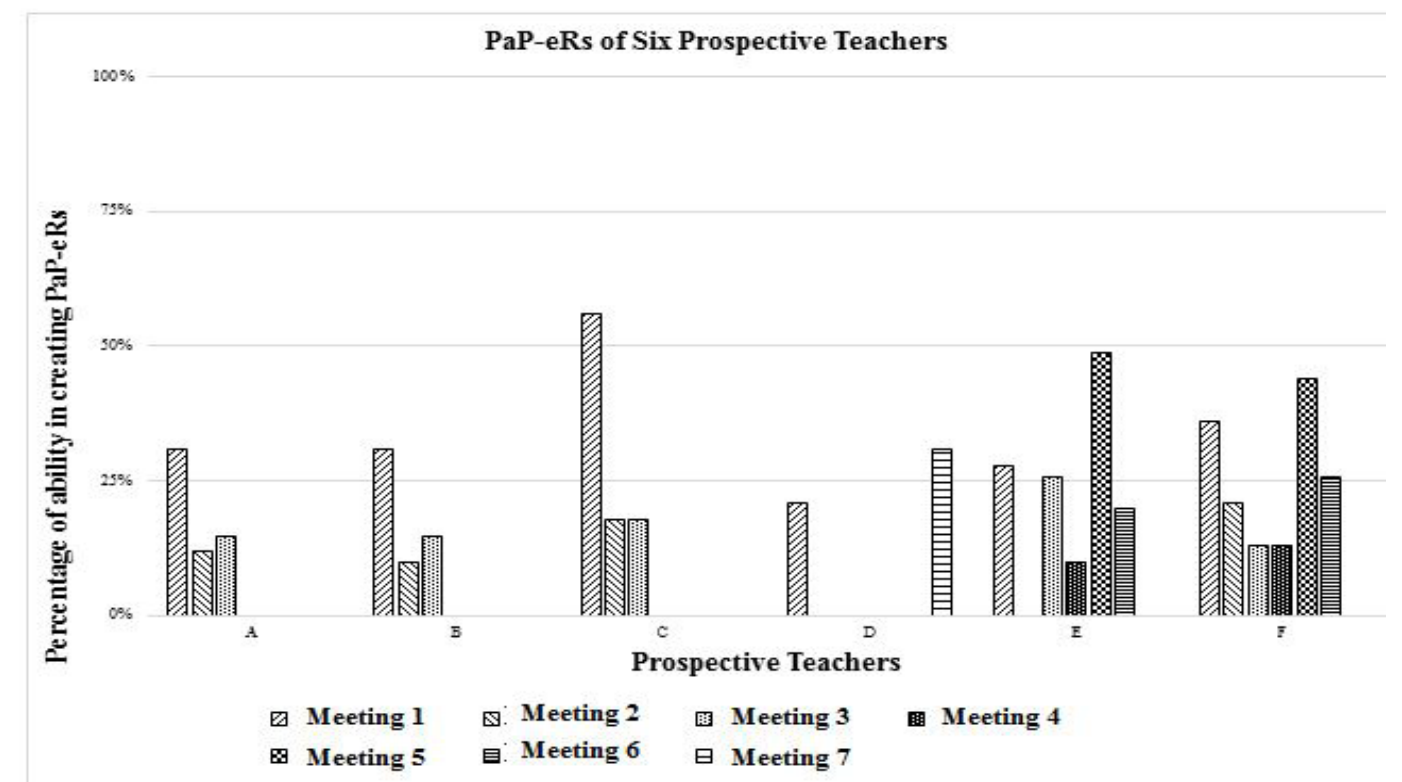

Figure 2. Ability of Prospective Teachers in Creating PaP-eRs 
Figure 2 shows that five from six prospective teachers create PaP-eRs according to the number of learning meetings conducted, while one of them creates only two PaP-eRs from seven meetings of learning. However, the number of PaP-eRs made does not affect the result of the PaP-eRs analysis as a representation of the ability to reflect on learning. The ability of reflecting is part of the PCK ability of prospective teachers analyzed based on the content of PaP-eRs created by the prospective teachers. Overall, based on Figure 2, the ability of six prospective teachers in narrating the implementation of learning is still below $50 \%$. This shows that the prospective teachers have not been able to reflect on the whole learning in terms of its aspects.

Six prospective teachers create PaP-eRs with the narration of the implementation of learning covering introduction, core, and closing activities. In core activities, six prospective teachers do not overall narrate the learning that is implemented, so the narrative cannot be used as a reflection in learning. Actually the purpose of making PaP-eRs is to elaborate and provide insight into the interaction between students and teachers so that it can serve as a reflection of learning (Loughran et al., 2012; Mulhall et al., 2003). Therefore, the result of the analysis of six prospective teachers' ability in reflecting on learning through the creation of PaP-eRs has not demonstrated their ability of PCK to integrate content knowledge and pedagogy.

The result of the analysis of resource folios consisting of CoRe and PaP-eRs during the study shows that six prospective teachers already have content knowledge and pedagogy knowledge, but they are not yet integrated as a whole. The ability to integrate content knowledge with pedagogical knowledge is not yet fully owned by the prospective teachers so that the planning and reflection of learning has not shown the ability of PCK intact. The ability of PCK has not appeared fully because the experience of the six prospective teachers is still minimal.

\section{CONCLUSION}

Based on the result of the analysis of resource folios, the PCK ability of prospective teachers A, B, C, D, E, and F does not show PCK ability intact. This is demonstrated by CoRe and $\mathrm{PaP}-\mathrm{eRs}$ that have been made by the six prospective teachers during the study. In creating CoRe, six prospective teachers do not show the ability to integrate content knowledge with pedagogy knowledge. The description of each component of
CoRe is limited to answering questions alone. It is not used as a tool for planning learning so that it is only more content knowledge. Meanwhile, the narrative of learning (PaP-eRs) created by six prospective teachers after implementing learning cannot be used as a reflection of learning. The $\mathrm{PaP}-\mathrm{eRs}$ created by the six prospective teachers brings up the ability in pedagogy more. Thus, it can be concluded that the ability of PCK of prospective teachers $\mathrm{A}, \mathrm{B}, \mathrm{C}, \mathrm{D}, \mathrm{E}$, and $\mathrm{F}$ in planning and reflecting learning is still minimal. The lack of potential of A, B, C, D, E, and F teachers' skills is indicated by the unintegrated knowledge of the content and pedagogical knowledge they have in the CoRe and PaP-eRs that have been made.

The PCK ability of the prospective teachers is not an ability to be trained within a short period of time. "Program pengalaman lapangan" (PPL) cannot assure that the PCK ability of prospective teachers can develop well. Therefore, for further research it would be better if there is a continuous program related to PCK so that the ability of prospective teachers is more honed; and it would be better if the program is in the lecture.

\section{REFERENCES}

Anwar, Y., Rustaman, N. Y., \& Widodo, A. (2012). Kemampuan Subject Specific Pedagogy Calon Guru Biologi Peserta Program Pendidikan Profesional Guru (PPG) Yang Berlatar Belakang Basic Sains Pra dan Post Workshop. Jurnal Pendidikan IPA Indonesia, 1(2), 157-162.

Aydeniz, M., \& Kirbulut, Z. D. (2014). Exploring Challenges of Assessing Pre-Service Science Teachers' Pedagogical Content Knowledge (PCK). Asia-Pacific Journal of Teacher Education, 42(2), 147-166.

Bertram, A., \& Loughran, J. (2012). Science Teachers' Views on Cores and Pap-Ers as a Framework for Articulating and Developing Pedagogical Content Knowledge. Research in Science Education, 42(6), 1027-1047.

Brown, P., Friedrichsen, P., \& Abell, S. (2013). The Development of Prospective Secondary Biology Teachers PCK. Journal of Science Teacher Education, 24(1), 133-155.

Creswell, J. W. (2013). Research Design: Qualitative, Quantitative, and Mixed Methods Approaches. Sage publications.

Donnelly, D. F., \& Hume, A. (2015). Using Collaborative Technology to Enhance Pre-Service Teachers' Pedagogical Content Knowledge in Science. Research in Science \& Technologic al Education, 33(1), 61-87.

Etkina, E. (2010). Pedagogical Content Knowledge and Preparation of High School Physics Teachers. Physical Review Special Topics-Physics Education Research, 6(2), 13-18. 
Gess-Newsome, J., Taylor, J. A., Carlson, J., Gardner, A. L., Wilson, C. D., \& Stuhlsatz, M. A (2016). Teacher Pedagogical Content Knowledge, Practice, and Student Achievement. International Journal of Science Education, 1-20.

Hanuscin, D. L. (2013). Critical Incidents in The Development of Pedagogical Content Knowledge for Teaching The Nature of Science: A Prospective Elementary Teacher's Journey. Journal of Science Teacher Education, 24(6), 933-956.

Hume, A., \& Berry, A. (2011). Constructing CoResA Strategy for Building PCK in Pre-Service Science Teacher Education. Research in Science Education, 41(3), 341-355.

Iserbyt, P., Ward, P., \& Li, W. (2017). Effects of Improved Content Knowledge on Pedagogical Content Knowledge and Student Performance in Physical Education. Physical Education and Sport Pedagogy, 22(1), 71-88.

Kaya, O. N. (2009). The Nature of Relationships among The Components of Pedagogical Content Knowledge of Preservice Science Teachers: 'Ozone Layer Depletion'as an Example. International Journal of Science Education, 31(7), 961-988.

Sagır, S. U., \& Küçükaydın, M. A. (2016). Loughran, J., Berry, A. and Mulhall, P.(2012). Understanding and Developing Science Teachers' Pedagogical Content Knowledge. Ilkögretim Online, 15(1).

Mulhall, P., Berry, A., \& Loughran, J. (2003, December). Frameworks for Representing Science Teachers' Pedagogical Content Knowledge. In Asia-Pacific Forum on Science Learning and Teaching 4(2), 1-25.
Nilsson, P. (2014). When Teaching Makes a Difference: Developing Science Teachers' Pedagogical Content Knowledge through Learning Study. International Journal of Science Education, 36(11), 1794-1814.

Nilsson, P., \& Loughran, J. (2012). Exploring The Development of Pre-Service Science Elementary Teachers' Pedagogical Content Knowledge. Journal of Science Teacher Education, 23(7), 699721.

Nilsson, P., \& Vikström, A. (2015). Making PCK Explicit-Capturing Science Teachers' Pedagogical Content Knowledge (PCK) in the Science Classroom. International Journal of Science Education, 37(17), 2836-2857.

Nurmatin, Suci; Rustaman, N. (2015). Potret Kemampuan Subject Specific Pedagogic Content Knowledge Calon Guru Sains dalam Merencanakan Pembelajaran Melalui Pembuatan CoRe. Journal Pendidikan IPA Indonesia, 4(1), 60-66.

Seung, E. (2013). The Process of Physics Teaching Assistants' Pedagogical Content Knowledge Development. International Journal of Science \& Mathematics Education, 11(6), 1303-1326.

Seung, E., Bryan, L. A., \& Haugan, M. P. (2012). Examining Physics Graduate Teaching Assistants' Pedagogical Content Knowledge for Teaching A New Physics Curriculum. Journal of Science Teacher Education, 23(5), 451-479.

Wahyuni, S. (2015). Developing Web-Based Performance Assessment in Integrated Science Course. Jurnal Pendidikan IPA Indonesia, 4(1), 7-10. 